\title{
Two sibs with unbalanced translocations in the Waardenburg gene region
}

\author{
L I Al Gazali, Roger Quaife
}

\begin{abstract}
We report two sibs with unbalanced translocations between chromosomes 2 and 11, both products of a paternal balanced reciprocal translocation involving bands 2 q37.3 and 11q23.3. ( $\mathcal{H}$ Med Genet 1993;30:607-9)
\end{abstract}

Recently Norman et $a l^{1}$ reported a similar translocation to the one we describe here, but in their case involving region 2q35. Like theirs, our translocation is of relevance to the mapping of the type I Waardenburg syndrome gene.

\section{Case reports}

The family consisted of a 32 year old father and a 28 year old mother. They have one normal and two affected children. The mother has had two miscarriages, both at 2 months' gestation. A sixth conception reached term but the child had multiple congenital malformations and died at the age of 2 days.

From a second wife there was a total of 13 pregnancies, nine of which ended in early spontaneous abortion. Four of these pregnancies went to term and resulted in two normal and two abnormal children, the latter each having multiple congenital malformations, one dying at 2 days and the other at 3 years.

We were able to examine and karyotype the father and mother and two affected children from the first marriage.

Case 1 was a 7 year old boy, the product of a normal pregnancy and delivery. Birth weight was $2460 \mathrm{~g}$, length $47 \mathrm{~cm}$, and head circumference $35 \mathrm{~cm}$. At birth he was noted to have the following dysmorphic features: large anterior fontanelle $(6 \times 6 \mathrm{~cm})$ and hypertelorism with inner canthal distance of $2.5 \mathrm{~cm}$, interpupillary distance of $4.5 \mathrm{~cm}$, and palpebral fissure length of $2 \mathrm{~cm}$. The ears were low set and folded on top. There was bilateral ptosis, cloudy corneas, and marked congestion of the conjunctiva. The possibility of congenital glaucoma was ruled out, but he was unable to close his eyes even during sleep and needed tarsorraphy. In addition, there was a single umbilical artery, hypospadias, and shawl scrotum. $X$ rays showed a small first metacarpal and hemivertebrae at T12. Skull $x$ ray showed the presence of wormian bones and no ossification of the lateral aspect of the orbit. He has suffered from excess tear production, congested conjunctiva, and severe photophobia since birth. At the age of 4 years he developed bilateral hydronephrosis owing to pelviureteric obstruction which was corrected surgically. Examination at the age of 7 years showed a severely retarded boy with a weight of $9.76 \mathrm{~kg}$, height of $87 \mathrm{~cm}$, and the following dysmorphic features: flat occiput, high and hairy forehead, low set ears, joined eyebrows, and large eyes with long eyelashes (fig 1). The inner canthal distance was $3 \mathrm{~cm}$ and interpupillary distance was $6 \mathrm{~cm}$. There is some scarring of the cornea and severe congestion of the conjunctiva. His nose is short, upturned, and has a depressed bridge. He has a long, smooth philtrum with a large, Cupid shaped mouth and hypodontia. The hands and feet are small, the fingers are spindle shaped with bilateral clinodactly, and there is overriding of the second and third toes bilaterally. He also has hypospadias with a minor degree of shawl scrotum. Auscultation indicated a grade $3 / 6$ systolic murmur at the left sternal edge. Echocardiography and CT scan of the brain were normal. The auditory evoked responses were normal.

Case 2, a $2 \frac{1}{2}$ year old girl, was the product of a normal pregnancy and delivery. Birth weight was $2500 \mathrm{~g}$. At birth she was noted to have hypotonia with long fingers and bilateral dislocation of the hips. She suffered from repeated attacks of stridor and was found to have laryngomalacia. At the age of $1 \frac{1}{2}$ years she developed repeated attacks of convulsions which were controlled by phenobarbitone. CT scan of the brain and echocardiography were normal. Examination at the age of $2 \frac{1}{2}$ years showed a moderately retarded girl with a weight of $12 \mathrm{~kg}$, height of $88.5 \mathrm{~cm}$, and the following dysmorphic features: prominent forehead with low anterior hair line, depressed nasal tip with short philtrum, and long, prominent upper lip (fig 2). She continues to be hypotonic with lax joints and bilateral dislocation of the hips. There is some limitation of movement at the elbow joint. She had a bilateral inguinal hernia which was corrected surgically. Skeletal sur-

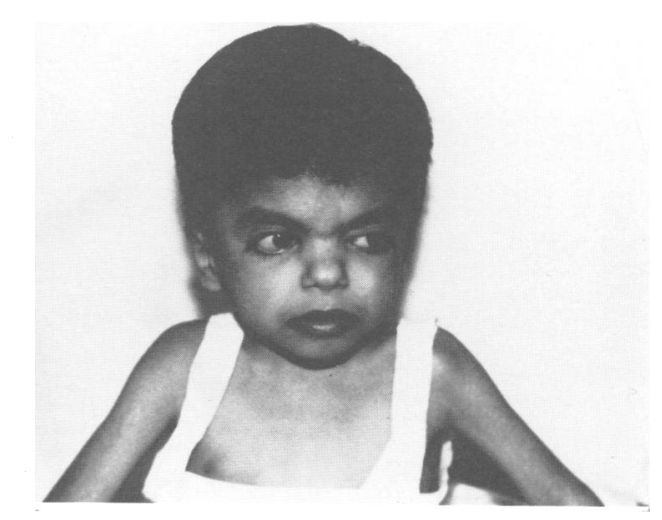

Figure 1 Facial appearance of case 1. 


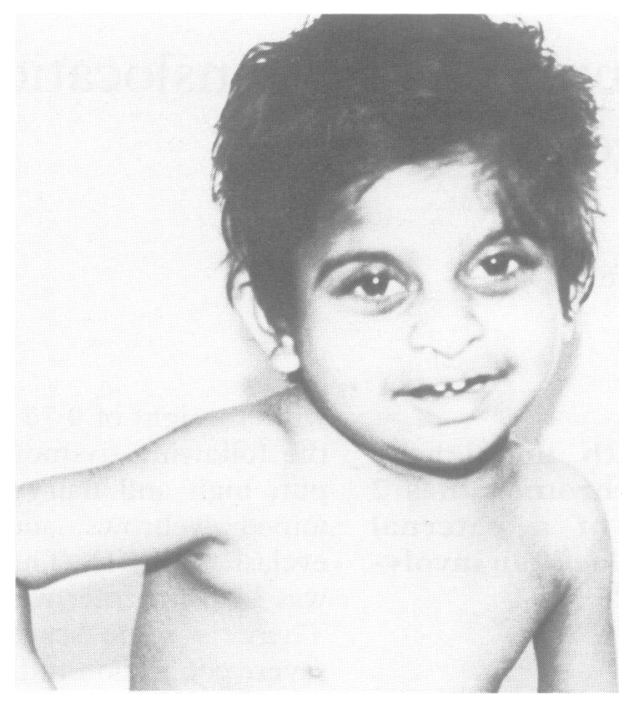

Figure 2 Facial appearance of case 2.

vey was normal apart from bilateral dislocation of the hips. Metabolic screen was normal.

Prometaphase banding showed a balanced reciprocal translocation involving chromosomes 2 and 11 in the father: $46, \mathrm{XY}, \mathrm{t}(2 ; 11)$ (q37.3;q23.3) (fig 3). The two children described above had unbalanced segregants from
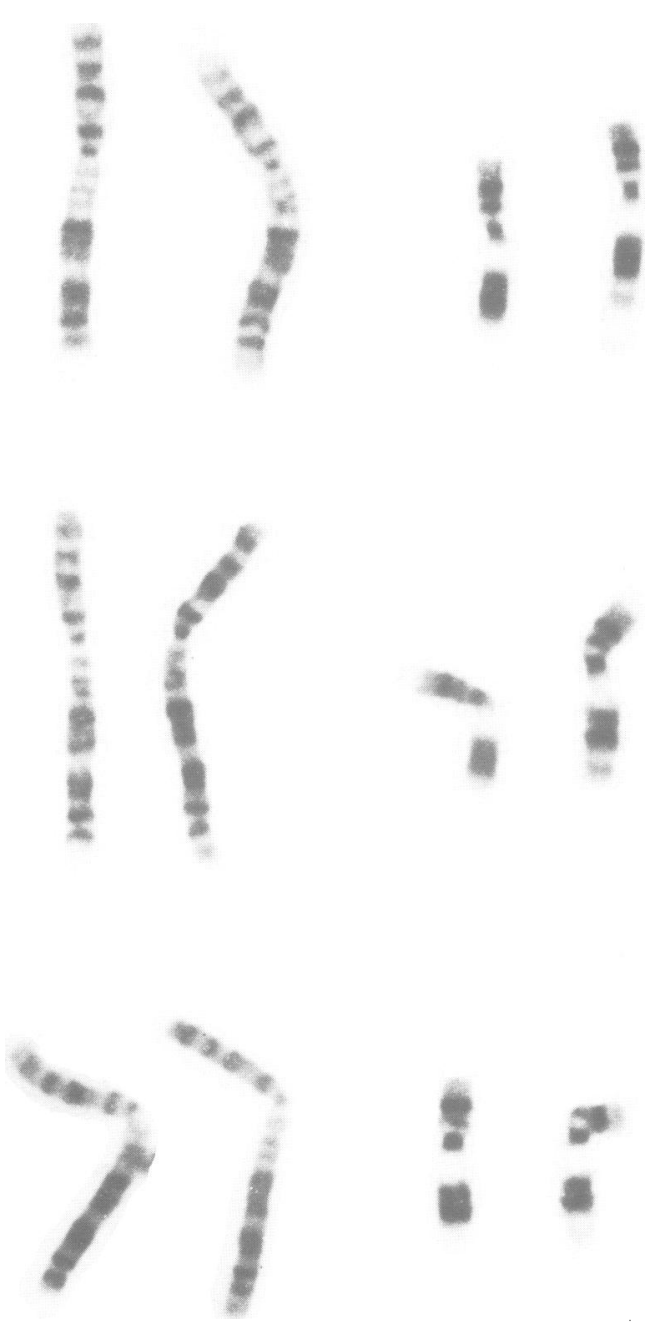

Figure 3 Partial karyotypes showing the balanced translocation in the father. this translocation, $46, \mathrm{XY},-11,+\operatorname{der} 11, \mathrm{t}(2 ; 11)$ (q37.3; 23.3$)$ and $46, \mathrm{XX},-2,+\operatorname{der} 2, \mathrm{t}(2 ; 11)$ (q37.3;q23.3), that is, the male was trisomic for the distal part of chromosome 2 at band q37.3 and monosomic for the distal region of chromosome 11 at band 23.3. The female was the reverse of this situation. Both children were the result of adjacent I segregation at meiosis 1 , typical of translocations involving small chromosome segments. The high early spontaneous abortion rate seen in the families described here was presumably because of adjacent II segregation products in the father.

\section{Discussion}

A de novo inversion described by Ishikiriyama et $a l^{2}$ suggested the gene for Waardenburg syndrome (WS) was likely to be situated at either $2 \mathrm{q} 35$ or $2 \mathrm{q} 37.3$. Foy et $a l^{3}$ and Asher et $a l^{4}$ showed linkage between the locus for placental alkaline phosphatase (ALPP) and WS. Norman et $a l^{1}$ have recently reported a similar translocation to the one described here but involving 2q35 rather than $\mathrm{q} 37$. However, neither the balanced carrier nor the fetus with partial trisomy for chromosome 2 described by Norman et $a l^{1}$ had features of WS. If the ALPP locus has been correctly assigned to $2 \mathrm{q} 37^{35}$ then unless there is more than one mutation for WS the gene should be at 2 q 37 . However, neither our balanced carrier father nor the partially trisomic child showed any symptoms of the syndrome. A reasonable interpretation of these data is that neither $A L P P$ nor $W S$ are at $2 \mathrm{q} 37$, but either at $2 \mathrm{q} 35$ or between $2 \mathrm{q} 35$ and $2 \mathrm{q} 37$. Alternatively, it may be that unless a rearrangement involves precisely the recently reported HuP2 gene ${ }^{67}$ there is no phenotypic expression.

Our family did show features which could be considered to be consistent with over- and under-expression of genes known to be at 2q37 and $11 \mathrm{q} 23$. Thus, for example, the male has monosomy $11 \mathrm{q} 23$ with the possible consequence of under-expression of the neural cell adhesion gene. This may in part explain his severe mental retardation since this gene is important in early embryonic cells in neural cell formation and differentiation. ${ }^{8}$ Similarly, the female has persistent hypotonia with lax joints perhaps reflecting the under-expression of the collagen VI, $\alpha 3$ chain gene. At the same time she may have over-expression of the apolipoprotein genes A-I, A-IV, and C-III, but as yet we are unable to confirm this. Furthermore, a suggested locus for tuberous sclerosis is at $11 \mathrm{q}^{2} 3^{9}$ but although this patient was partially trisomic for this region she did not show any features of this disease. As well as under- and over-expression of genes, recessive disorders may be expressed in the partially monosomic subjects. However, in our patients we have no clear indication of recessivity.

Finally, both our unbalanced translocation patients and those described by Norman $e t$ al ${ }^{1}$ resulted from a translocation in the father and therefore are based upon the same uniparental disomy for the trisomic regions which are both relatively close. Since it is known that imprint- 
ing can affect gene expression depending on whether both sets or parts of both chromosomes are of paternal or maternal origin, ${ }^{10}$ it may be prudent to await in situ mapping studies using the HuP2 gene itself which would show its precise chromosomal location.

The manuscript was kindly typed by P Roberts.

\section{Note added in proof}

The Waardenburg syndrome gene has now been mapped by fluorescence in situ hybridisation to 2q35 (Tsukamoto K, Tohma T, Ohta $\mathrm{T}$, et al. Cloning and characterization of the inversion breakpoint at chromosome $2 \mathrm{q} 35$ in a patient with Waardenburg syndrome type 1 . Hum Mol Genet 1992;1:315-17).

1 Norman AM, Read AP, Clark A, Haslam J, Donnai D.
Fetus with unbalanced translocation involving chromo-

2 Ishikiriyama S, Tonoki H, Shilriya Y, et al. Waardenburg shikiriyama $S$, Tonoki $H$, Shilriya Y, et al. Waardenburg
syndrome type I in a child with de novo inversion syndrome type I in a child with de novo
(2)(q35q37.3). Am $\mathcal{F}$ Med Genet 1989;33:505-7.

3 Foy C, Newton V, Wellesley D, Harris R, Read AP Assignment of the locus for Waardenburg syndrome type I to human chromosome $2 \mathrm{q} 37$ and possible homology to the splotch mouse. Am $\mathcal{F}$ Hum Genet 1990;46:1017-23.

4 Asher JH, Morell R, Friedman TB. Waardenburg syndrome (WS): the analysis of a single family with WSI
mutation showing linkage to RFLP markers on human mutation showing linkage to RFLP markers on hu
chromosome $2 \mathrm{q}$. Am $\mathcal{J}$ Hum Genet 1991;48:43-52.

5 Martin D, Tucker DF, Gorman P, Sheer D, Spurr NK Trowsdale J. The human alkaline phosphatase gene and related sequences map to chromosome 2 band $2 \mathrm{q} 37 . \mathrm{Am} \mathcal{F}$ Hum Genet 1987;51:145-52.

6 Tassabehji M, Read AP, Newton VE, et al. Waardenburg's syndrome patients have mutations in the human homo-
logue of the pax-3 paired box gene. Nature 1992;355:635-6.

7 Baldwin CT, Hoth CF, Amos JA, da-Silva EO, Milunsky A. An exonic mutation in the HuP2 paired domain gene A. An exonic mutation in the HuP2 paired domardenburg's syndrome. Nature 1992;355:637-8.

8 Ngyugen C, Mattei M, Mattei J, Sartoni M, Goridis C, Jordan B. Localization of the human NCAM gene to band q23 of chromosome 11. I Cell Biol 1986;102:711-15.

9 Clark RD, Smith M, Pandolfo M, Fansel RE, Buftillo AM. Tuberous sclerosis in a live born infant with trisomy due to (11q23.3;22q11.2) translocation. Am $\mathcal{F}$ Hum Genet 1988;43:44.

10 Hall JG. Genomic imprinting: review and relevance to human diseases. Am f Hum Genet 1990;46:857-930. 